\title{
Synthesis, characterization and biological studies of cobalt(II), nickel(II), copper(II) and zinc(II) complexes of vanillin-4-methyl-4- phenyl-3-thiosemicarbazone
}

\author{
LEKSHMI V KUMAR (1) and G RATHIKA NATH* (D) \\ PG and Research Department of Chemistry, KSM DB College, Sathamcottta, Kollam, Kerala 690 521, India \\ E-mail: rakhignath@yahoo.com
}

MS received 5 April 2019; revised 2 June 2019; accepted 3 June 2019

\begin{abstract}
Complexes of vanillin-4-methyl-4-phenyl-3-thiosemicarbazone with cobalt(II), nickel((II), copper(II) and zinc(II) metal ions were synthesized and characterized by elemental analysis, molar conductance, magnetic moment, infrared spectra, electronic spectra, ${ }^{1} \mathrm{H}$ and ${ }^{13} \mathrm{C}$ NMR, mass spectrum and thermal analysis. The low molar conductance values indicate that all the complexes are non-electrolytes. Spectral studies indicate that the ligand act in a tridentate manner coordinating with the metal ion through sulphur, oxygen and nitrogen atoms. Based on magnetic moment measurements, spectral studies and thermal analysis, suitable geometry was proposed for the metal complexes. Thermal stability of the complexes was ascertained on the basis of thermo gravimetric analysis and the lattice parameters, space group and grain size of the ligand and complexes were determined by using powder XRD measurements. Surface morphology of ligand and complexes were studied using SEM analysis. Antimicrobial studies were carried out against gram-positive, gram-negative bacteria and two fungal pathogens.
\end{abstract}

Keywords. Thiosemicarbazone; transition metal complexes; antimicrobial study.

\section{Introduction}

Thiosemicarbazones find various applications depending on the donor atoms of ligands, their flexibility and their ability to coordinate either in neutral or deprotonated form. ${ }^{1-3}$ Thiosemicarbazones are chelating ligands and their complexes are tools useful for a variety of bioinorganic process. ${ }^{4,5}$ Thiosemicarbazones commonly act as bidentate ligand through nitrogen and sulphur atoms. The presence of additional donor groups attached to the thiosemicarbazone moiety helps them to behave as tridentate ligands also. ${ }^{8,9}$ Biological activity is shown by thiosemicarbazone derivatives of aldehydes and ketones. ${ }^{10,11}$ Earlier reports show that their metal complexes, due to their ability to form stable chelates with essential metal ions, exhibit enhanced activity. ${ }^{12-15}$ Certain thiosemicarbazones complexes were reported to have applications as nanoprecursor. ${ }^{16,17}$

The present study reports the synthesis, characterization and biological activities of cobalt, nickel, copper and zinc complexes of vanillin-4-methyl-4-phenyl-3thiosemicarbazone. Biological activity was carried out on two Gram-positive bacteria - Staphylococcus aureus and Bacillus cereus, two-gram negative bacteria - Escherichia coli and Klebsiella pneumonia and two fungal pathogens - Aspergillus niger and Penicillium sp.

\section{Experimental}

Analar grade solvents and chemicals were used. Transition metal(II) salts (cobalt/nickel/copper and zinc chlorides), carbon disulfide, $\mathrm{N}$-methyl aniline, sodium hydroxide, sodium chloroacetate, hydrazine hydrate and $\mathrm{HCl}$ were purchased from Sigma Aldrich and Merck chemicals. Solvents used for physicochemical measurements were purified by standard methods.

Elemental analysis for $\mathrm{C}, \mathrm{H}, \mathrm{N}$ and $\mathrm{S}$ were carried out using ElementarVario EL III CHN analyzer. The magnetic susceptibility measurements were carried out by Gouy's method using $\mathrm{Hg}\left[\mathrm{Co}(\mathrm{SCN})_{4}\right]$ as calibrant. Diamagnetic

*For correspondence

Electronic supplementary material: The online version of this article (https://doi.org/10.1007/s12039-019-1658-x) contains supplementary material, which is available to authorized users. 
corrections were made using Pascal constants. Molar conductance measurements were carried out using $10^{-3} \mathrm{M}$ solutions of the complexes in DMSO solvent at room temperature using digital conductivity meter. Infrared spectra of the ligand and its complexes were recorded using potassium bromide pellets in the range of $4000-400 \mathrm{~cm}^{-1}$ on a Perkin Elmer FT-IR spectrophotometer and the electronic spectra of the ligand and its complexes were recorded using Genesys 10S-UV-VIS spectrophotometer in DMSO solvent. The NMR spectrum was taken in BRUKER Avance -III $400 \mathrm{MHz}$ NMR spectrometer, using DMSO-d $\mathrm{d}_{6}$ as solvent. Powder XRD measurements were conducted using Bruker D.8 Advance X-ray diffractometer. The thermogravimetric analysis was carried out ranging from room temperature to $800^{\circ} \mathrm{C}$ in a Perkin Elmer Diamond TG/DTA at a heating rate of $10^{\circ} \mathrm{C}$.

\subsection{Preparation of vanillin 4-methyl-4-phenyl-3- thiosemicarbazone [HVTS]}

A mixture of carbon disulfide $(12 \mathrm{~mL}, 0.20 \mathrm{~mol})$ and $\mathrm{N}$-methylaniline $(21.6 \mathrm{~mL}, 0.20 \mathrm{~mol})$ was treated with sodium hydroxide $(8.2 \mathrm{~g}, 0.20 \mathrm{~mol})$ dissolved in $250 \mathrm{~mL}$ water. After stirring the solution for $4 \mathrm{~h}$ at room temperature, the colour of the solution changed from orange to straw coloured and at this point, sodium choloroacetate $(23.2 \mathrm{~g}, 0.20 \mathrm{~mol})$ was added, stirred and allowed to stand for $24 \mathrm{~h}$. The solution was then acidified with conc. $\mathrm{HCl}$. The resulting solid Carboxymethyl N-methyl-N-phenyl dithiocarbamate was separated by filtration and washed with dil. $\mathrm{HCl}$ and dried. Then a mixture of carboxymethyl$\mathrm{N}$-methyl-N-phenyldithiocarbamate, $10 \mathrm{~mL}$ of hydrazine hydrate and $5 \mathrm{~mL}$ of water was heated on a water bath for half an hour. Purity of the sample was checked by using thin-layer chromatographic technique. The compound separated was filtered, washed with water, dried and recrystallized from ethanol and dried to collect the ligand as white needle-like solid. Yield: $78 \%$, M.p.: $168{ }^{\circ} \mathrm{C}, \mathrm{C}_{16} \mathrm{H}_{17} \mathrm{~N}_{3} \mathrm{O}_{2} \mathrm{~S}$, Anal. Found(\%): C, 60.91; H, 5.42; N, 13.35; S, 10.16. Calcd. for(\%):C, 60.93; H, 5.43; N, 13.32; S, 10.17 . $\operatorname{IR}\left(\mathrm{KBr}, \gamma / \mathrm{cm}^{-1}\right):\left(\gamma_{\mathrm{OH}}\right) 3400,\left(\gamma_{\mathrm{NH}}\right) 3438,\left(\gamma_{\mathrm{C}=\mathrm{S}}\right) 824$, $\left(\gamma_{\mathrm{C}=\mathrm{N}}\right) 1609 .{ }^{1} \mathrm{H}$ NMR(400 MHz,DMSO-d $\left.{ }_{6}, \mathrm{TMS}\right): \delta 11.32$ $(1 \mathrm{H}, \mathrm{S}, \mathrm{OH}), 2.32\left(3 \mathrm{H}, \mathrm{s}, \mathrm{OCH}_{3}\right), 7.4-8.21(5 \mathrm{H}, \mathrm{m}, \mathrm{ArH})$, 6.97-6.9 (3H, m, Ar-H), $8.362 \quad\left(2 \mathrm{H}, \quad \mathrm{s}, \quad \mathrm{NH}_{2}\right)$. ${ }^{13} \mathrm{CNMR}(\mathrm{ppm}): 181,147.95,146.83,144.54,144,129.81$, 127.35, 126.49, 121.3, 118.70, 113.16., ESI-MS(m/z): calc: 315.39 Found: 316 (Scheme 1).

\subsection{Synthesis of complexes with vanillin 4-methyl- 4-phenyl-3-thiosemicarbazone [HVTS]}

A hot methanolic solution ( $30 \mathrm{~mL})$ of vanillin-4-methyl-4phenyl-3-thiosemicarbazone $(0.630 \mathrm{~g}, 2 \mathrm{mmol})$ was added dropwise to a hot methanolic solution $(30 \mathrm{~mL})$ of $1 \mathrm{mmol}$ cobalt chloride $(0.237 \mathrm{~g} / 1 \mathrm{mmol})$, nickel chloride $(0.237 \mathrm{~g}$,

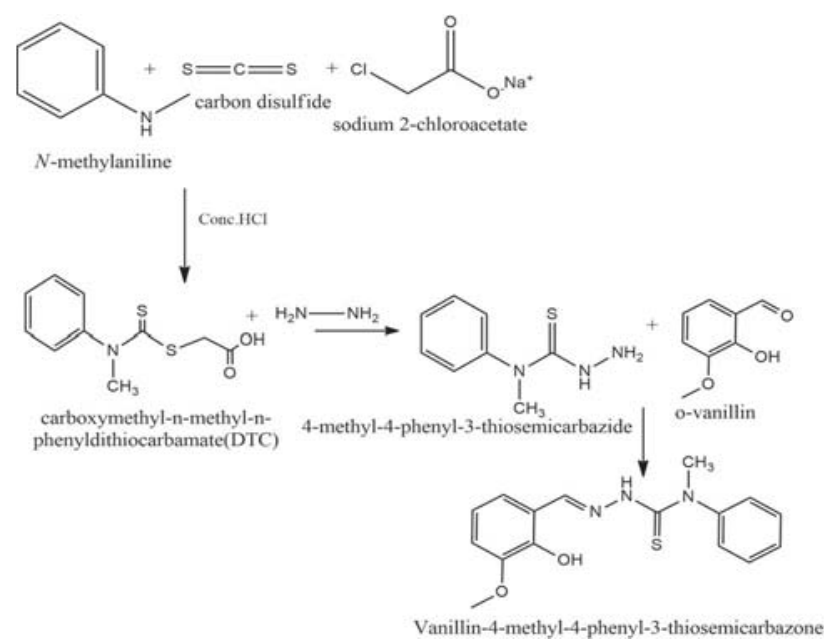

Scheme 1. Synthesis of ligand.

$1 \mathrm{mmol}) / \mathrm{copper}$ chloride $(0.340 \mathrm{~g}, 2 \mathrm{mmol}) / \mathrm{zinc}$ chloride $(0.272 \mathrm{~g}, 2 \mathrm{mmol})$ with continuous stirring and heated on a water bath at $75^{\circ} \mathrm{C}$ for $4 \mathrm{~h}$. The coloured complexes formed were filtered, washed with methanol to remove unreacted ligand and then dried in vacuum.

2.2a $\mathrm{Co}(\mathrm{II})$ complex: Brown solid; Yield; $81 \%$, M.p.; 242 ${ }^{\circ} \mathrm{C}$, Anal. Found(\%): C, 55.86; H, 4.68; N, 12.25; S, 9.37. Calc(\%).:C,55.89; H,4.69; N, 12.22; S,9.33，IR(KBr, $\gamma /$ $\left.\left.\mathrm{cm}^{-1}\right)\right):\left(\gamma_{\mathrm{NH}}\right) 3433,\left(\gamma_{\mathrm{C}=\mathrm{S}}\right) 778,\left(\gamma_{\mathrm{C}=\mathrm{N}}\right) 1596,\left(\gamma_{\mathrm{M}-\mathrm{S}}\right) 427$, $\left(\gamma_{\text {M-O }}\right) 547,\left(\gamma_{\text {M-N }}\right) 466$.

2.2b Ni(II) complex: Black solid; Yield; $82 \%$, M.p.; $162{ }^{\circ} \mathrm{C}$, Anal. Found(\%): C,55.93; H, 4.71; N, 12.18; S, 9.35. Calc(\%).:C,55.91; H,4.69; N, 12.22; S,9.33, IR(KBr, $\gamma /$ $\left.\left.\mathrm{cm}^{-1}\right)\right):\left(\gamma_{\mathrm{NH})} 3442,\left(\gamma_{\mathrm{C}=\mathrm{S}}\right) 779,\left(\gamma_{\mathrm{C}=\mathrm{N}}\right) 1588,\left(\gamma_{\mathrm{M}-\mathrm{S}}\right) 412\right.$, $\left(\gamma_{\mathrm{M}-\mathrm{O}}\right) 550,\left(\gamma_{\mathrm{M}-\mathrm{N}}\right) 465$.

2.2c $\mathrm{Cu}(\mathrm{II})$ complex: Black solid; Yield; 80\%, M.p.; 192 ${ }^{\circ} \mathrm{C}$, Anal. Found(\%): C,42.74; H, 4.51; N, 9.36; S, 7.14. Calc(\%).:C,42.76; H,4.49; N, 9.35; S,7.13, IR(KBr, $\gamma /$ $\left.\left.\mathrm{cm}^{-1}\right)\right):\left(\gamma_{\mathrm{NH})} 3446,\left(\gamma_{\mathrm{C}=\mathrm{S}}\right) 777,\left(\gamma_{\mathrm{C}=\mathrm{N}}\right) 1592,\left(\gamma_{\mathrm{M}-\mathrm{S}}\right) 412\right.$, $\left(\gamma_{\mathrm{M}-\mathrm{O}}\right) 555,\left(\gamma_{\mathrm{M}-\mathrm{N}}\right) 457$.

2.2d Zn(II) complex: Light yellow solid; Yield; 76\%, M.p.; $206{ }^{\circ} \mathrm{C}$, Anal. Found $(\%)$ : C,46.61; H, 3,64; N, 10.26; S, 7.53. Calc(\%).:C, 46.28; H,3.88; N, 10.12; S,7.72, IR(KBr, $\left.\left.\gamma / \mathrm{cm}^{-1}\right)\right):\left(\gamma_{\mathrm{NH}} 3404,\left(\gamma_{\mathrm{C}=\mathrm{S}}\right) 776,\left(\gamma_{\mathrm{C}=\mathrm{N}}\right) 1595,\left(\gamma_{\mathrm{M}-\mathrm{S}}\right) 421\right.$, $\left(\gamma_{\text {M-O }}\right) 564,\left(\gamma_{\text {M-N }}\right) 446$ (Scheme 2$)$.

\subsection{Antimicrobial study}

Antimicrobial activities of the samples were determined by agar well diffusion method. The media used for the antibacterial test was nutrient broth. The test bacterial strains were inoculated in nutrient broth and incubated at 37 ${ }^{\circ} \mathrm{C}$ for $24 \mathrm{~h}$. After the incubation period, the culture tubes were compared with the turbidity standard and used. Fresh bacterial culture of $0.1 \mathrm{~mL}$ having $108 \mathrm{CFU}$ was spread on the nutrient agar plate using a swab. Wells of $6 \mathrm{~mm}$ diameter were punched off into medium with a sterile cork 


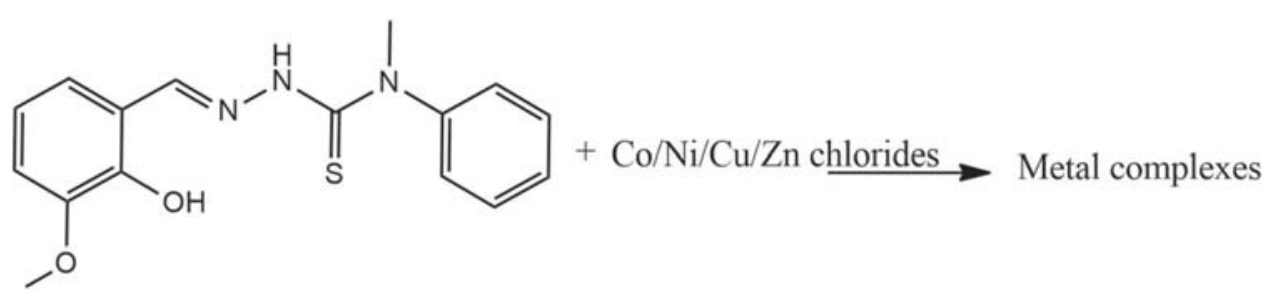

Scheme 2. Synthesis of complexes.

borer and filled with $50 \mu \mathrm{L}$ of the sample by using micropipette in each well in aseptic condition and standard antibiotic was also included as a control. Plates were kept in a refrigerator to allow pre-diffusion of extract for $30 \mathrm{~min}$. Further, the plates were incubated in an incubator at $37{ }^{\circ} \mathrm{C}$ for $24 \mathrm{~h}$ and the antimicrobial activity was evaluated by measuring the zone of inhibition.

Fungal inoculums were prepared by suspending the spores of a fungus (as previously cultured) in saline water, mixed thoroughly, made turbidity standard and used. A spore suspension of fresh fungal inoculums was spread on dextrose agar plates using sterile cotton swabs. After air dried, wells of $6 \mathrm{~mm}$ diameter were punched off into medium with a sterile cork borer and filled with $50 \mu \mathrm{L}$ (about $50 \mu \mathrm{g}$ ) of test sample using micropipette in aseptic condition. The plates were kept in a refrigerator to allow pre-diffusion of extract for $30 \mathrm{~min}$ and then incubated at 28-37 ${ }^{\circ} \mathrm{C}$ for 3-4 days. The activity was evaluated by measuring the zone of inhibition.

\section{Results and Discussion}

All the complexes were found to be stable at room temperature, insoluble in water and other organic solvents, but soluble in DMSO and DMF. Analytical data of the complexes were found to be in good agreement with their formulation. The molecular formula of the complexes were formulated as $\left[\mathrm{M}(\mathrm{VTS})_{2}\right]$ $\mathrm{M}=\mathrm{Co}(\mathrm{II}), \mathrm{Ni}(\mathrm{II}), \quad[\mathrm{Cu} \quad(\mathrm{VTS}) \mathrm{Cl}] \cdot 2 \mathrm{H}_{2} \mathrm{O}, \quad$ and [Zn(VTS)Cl], $\mathrm{M}=\mathrm{Cu}(\mathrm{II})$ and $\mathrm{Zn}(\mathrm{II})$, HVTS=vanillin4-methyl-4-phenyl-3-thiosemicarbazide. Cobalt and nickel complexes were found to possess 1:2 metalligand stoichiometry while copper and zinc complexes were found to possess 1:1 stoichiometry. The molar conductance values of the complexes in $0.001 \mathrm{M}$ DMSO solution lies in the range of $10-21 \Omega^{-1} \mathrm{~cm}^{2-}$ $\mathrm{mol}^{-1}$ at room temperature. These values confirm the non-electrolytic nature of the complexes. ${ }^{18,19}$

\section{$3.1{ }^{13} C-N M R$ spectrum}

The carbon skeleton of the thiosemicarbazone ligand was identified using ${ }^{13} \mathrm{C}-\mathrm{NMR}$ spectrum shown in Figure 1. Carbon attached to the $\mathrm{C}=\mathrm{S}$ group resonates at downfield shift at $181 \mathrm{ppm}^{20,21}$ The carbon atom of the phenyl ring attached to the aniline nitrogen also resonates at downward shift at $144 \mathrm{ppm}^{22}$ The signals of carbon atoms of the benzene ring attached with methoxy group and a hydroxyl group at 147.91 and $147.95 \mathrm{ppm}$ respectively. The signal of the carbon atom of azomethane at $146.83 \mathrm{ppm}$. The signal of the carbon atom of the phenyl ring attached to the nitrogen at $144.54 \mathrm{ppm}$. The carbon atom of the methyl group attached to the nitrogen resonates at $43.89 \mathrm{ppm}$ and methyl group attached to the vanillin derivative resonate at $55.78 \mathrm{ppm}$. The carbon atoms of the benzene ring were assigned to signal at $127.35 \mathrm{ppm}$ (ortho), $129.810 \mathrm{ppm}$ (meta), 126.49 (para) ppm respectively. ${ }^{23}$ The carbon atom of the benzene ring of vanillin resonates at $121.37,118.70,113.160 \mathrm{ppm}$ respectively.

\section{$3.2{ }^{1} H$-NMR spectrum}

The proton NMR spectra of the ligand and zinc complex are recorded in $\mathrm{d}_{6}$-dimethyl sulphoxide (DMSO- $\mathrm{d}_{6}$ ) using trimethylsilane as an internal standard. The chemical shifts of the different types of protons found in the NMR spectrum of the organic ligand is compared with that of the diamagnetic $\mathrm{Zn}$ (II) complex. The NMR spectra of the ligand at $11.32 \mathrm{ppm}$ indicate the presence of the phenolic $\mathrm{OH}$ group. ${ }^{24}$ The phenolic $\mathrm{OH}$ signal in the spectrum of the ligand is not seen in the spectrum of the zinc complex which indicates that the hydrogen atom of the phenolic group is absent in the complex. The hydrogen atom attached to the nitrogen atom of thiosemicarbazone appears as a singlet at $8.362 \mathrm{ppm}$. The signal due to azomethane proton gets shifted upon complexation, which is due to the donation of the lone pair of an electron by the nitrogen to the central metal atom resulting in the formation of a coordinate linkage. The protons of the methoxy group attached to the phenolic ring resonate at $2.37 \mathrm{ppm}$ as a singlet. ${ }^{25}$ The eight aromatic protons resonate in between $7.4-8,21 \mathrm{ppm}$ as muliplet in the ligand. $^{26}$ The signal due to the aromatic proton and methoxy proton was the same as that of the ligand with a small variation. The proton NMR spectrum of ligand and zinc complex are shown in Figures 2 and 3. 


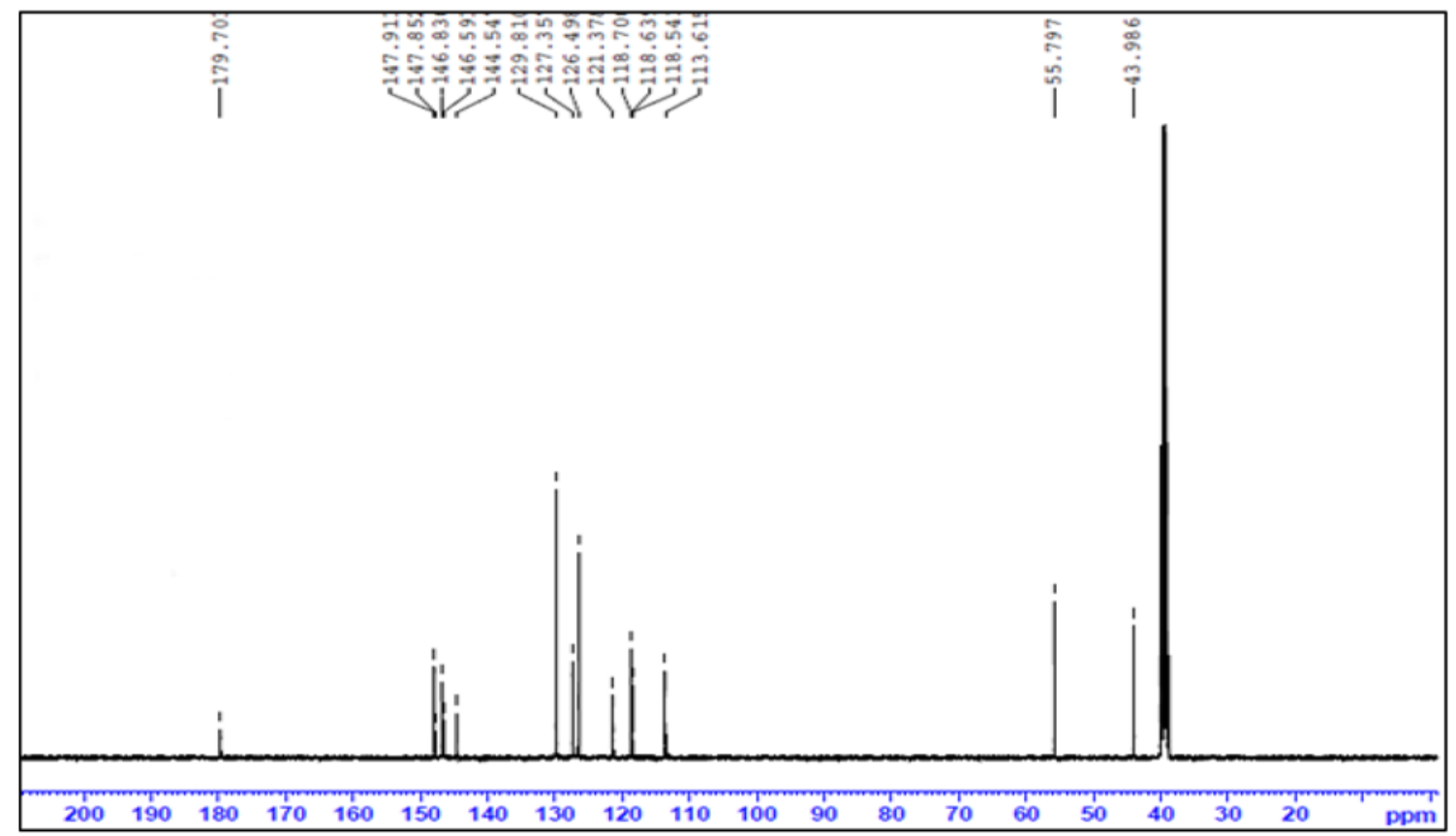

Figure 1. ${ }^{13} \mathrm{C}-\mathrm{NMR}$ spectrum of HVTS.

\subsection{Infrared spectra}

The most significant IR spectral band along with their tentative assignments are shown in Figure 4. The IR spectrum of the ligand was compared with that of the complexes to identify the changes during complexation. The spectrum of the ligand shows a band at 3400 $\mathrm{cm}^{-1}$ indicating the presence of $\mathrm{OH}$ group, which is absent in the spectra of complex confirming the deprotonation of the ligand towards the central metal atom. A broad band at 3400 and a new band at 865 in the spectra of the copper complex were assigned to $\mathrm{OH}$ group of a water molecule. ${ }^{27}$ The strong band observed at $1609 \mathrm{~cm}^{-1}$ in the spectra of the ligand is characteristic of azomethine stretching vibrations. Upon complexation, this vibration shifted to the lower

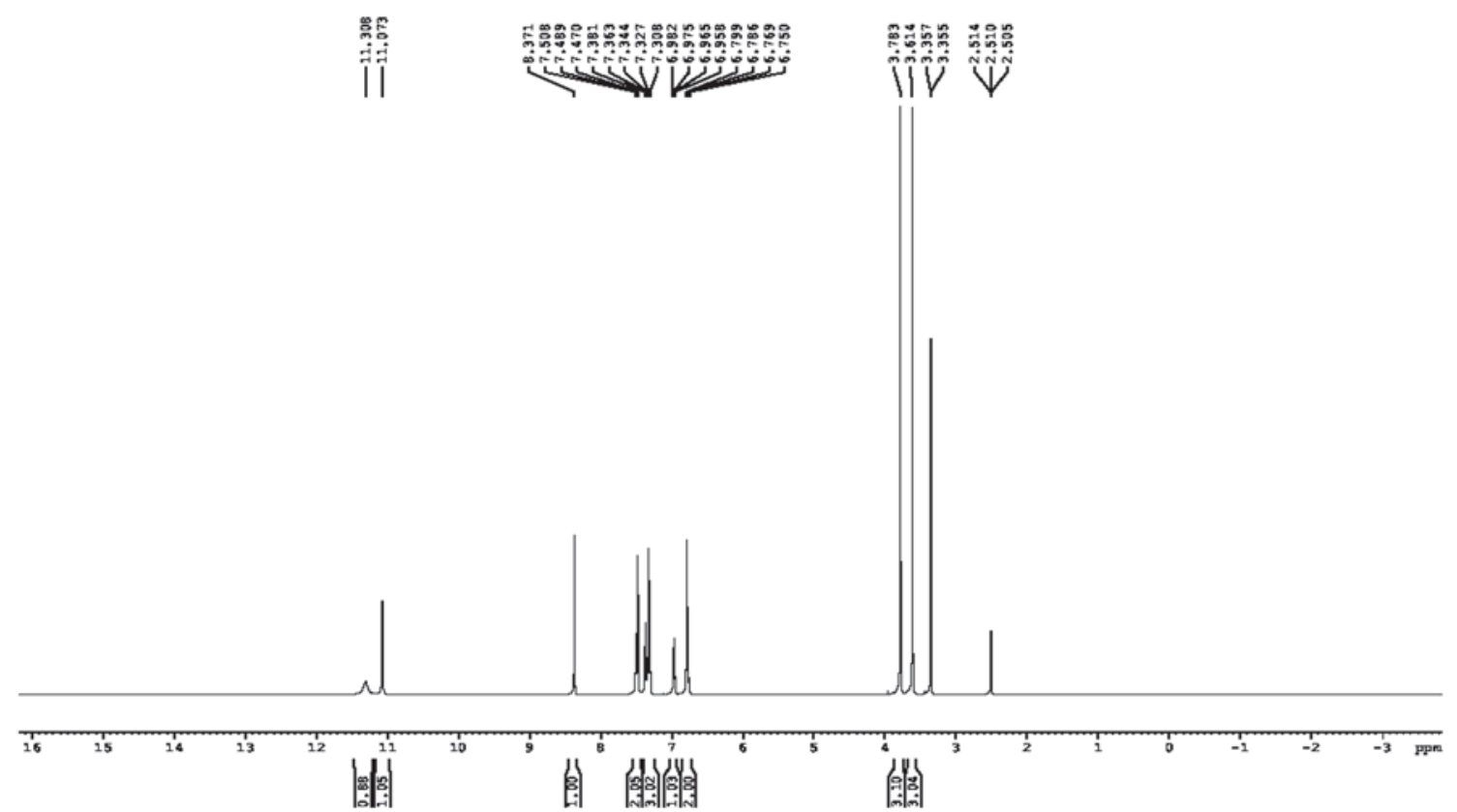

Figure 2. Proton NMR spectrum of HVTS. 


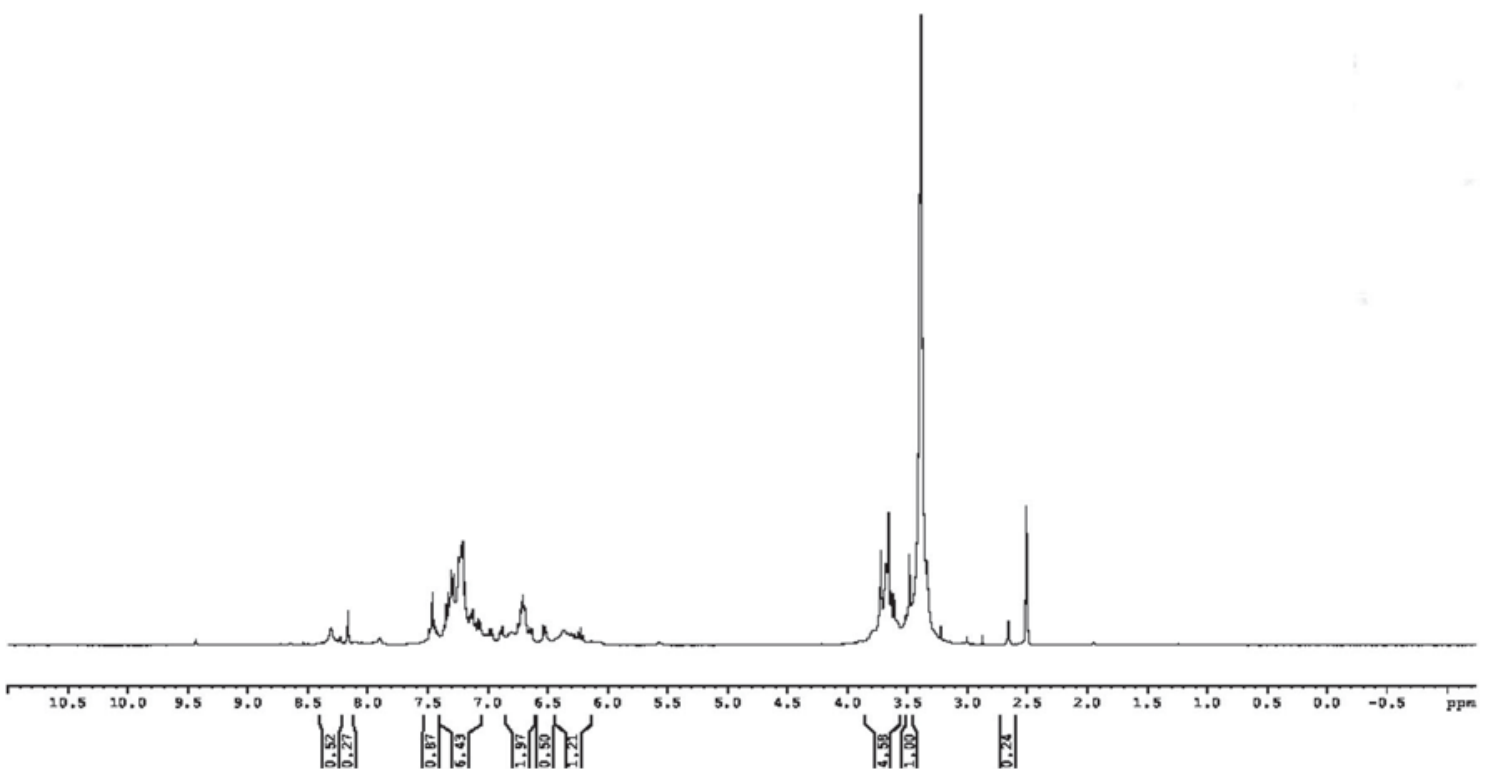

Figure 3. Proton NMR spectrum of $\left[\mathrm{Zn}(\mathrm{VTS})_{2} \mathrm{Cl}\right]$.

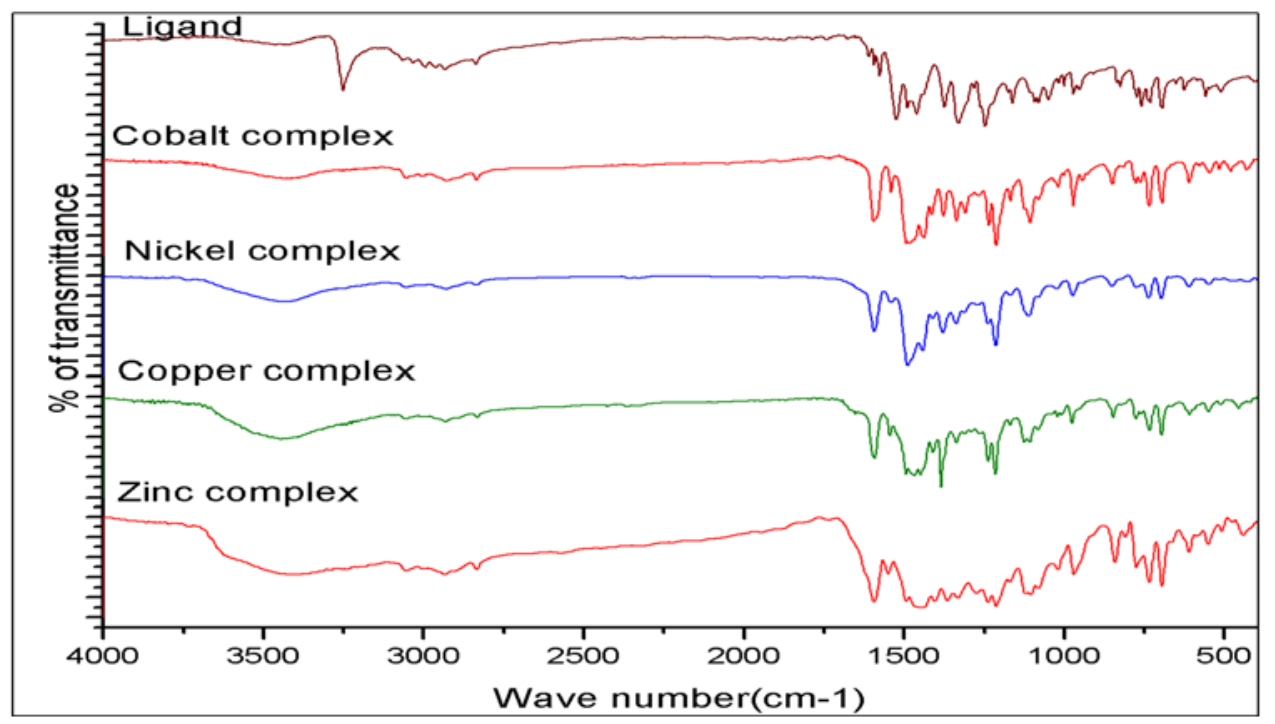

Figure 4. FTIR spectra of ligand and its complexes.

frequency range of $1585-1592 \mathrm{~cm}^{-1}$, indicating bonding of unsaturated nitrogen of azomethane group to the metal ions. ${ }^{28}$ The thiosemicarbazone ligand shows an intense band at $1162 \mathrm{~cm}^{-1}$ and less intense band at $824 \mathrm{~cm}^{-1}$ attributed to the $\mathrm{C}=\mathrm{S}$ vibration of the free ligand and absence of a peak at $2500 \mathrm{~cm}^{-1}$ indicates that the ligand is present in the thione form in the solid-state. As a result of complex formation, the band due to $\mathrm{C}=\mathrm{S}$ was shifted towards $750-800 \mathrm{~cm}^{-1}$ indicating the involvement of coordination of thioketo sulphur towards the metal ion. ${ }^{29}$ In the low-frequency region of complexes some new bands have been observed in the range of $400-430 \mathrm{~cm}^{-1}, 450-480$ $\mathrm{cm}^{-1}$ and $540-560 \mathrm{~cm}^{-1}$ attributed to the stretching frequency of M-S, M-N and M-O respectively. ${ }^{30,31}$ In the IR spectra of the chloro complexes of copper and zinc, the band corresponding to $310-350 \mathrm{~cm}^{-1}$ regions are tentatively assigned for $\mathrm{M}-\mathrm{Cl}$ bond. ${ }^{32}$

\subsection{Electronic spectra}

The electronic spectra of ligand and metal complexes were taken in DMSO solvent between $200-800 \mathrm{~nm}$ at $298 \mathrm{~K}$. The vanillin thiosemicarbazone ligand exhibits 


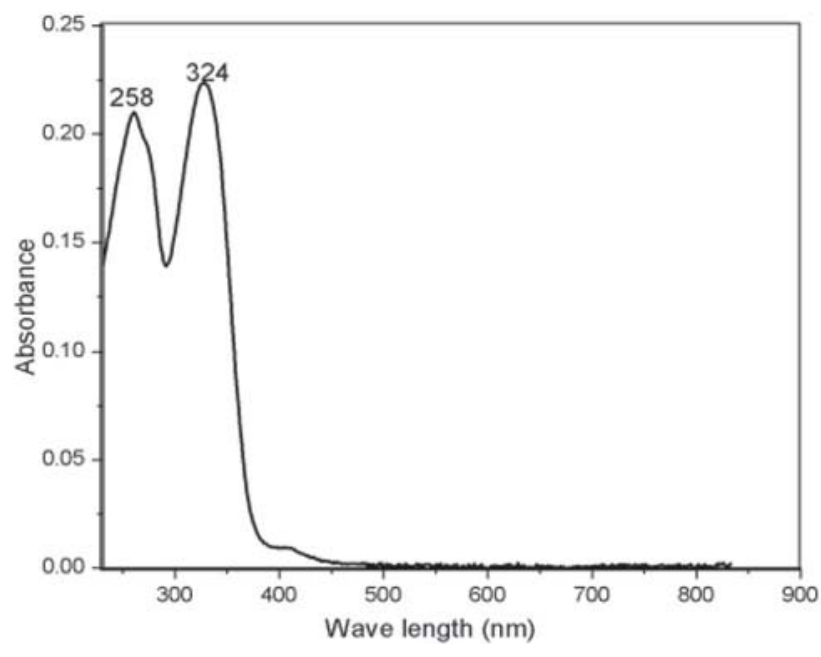

Figure 5. UV spectrum of HVTS.

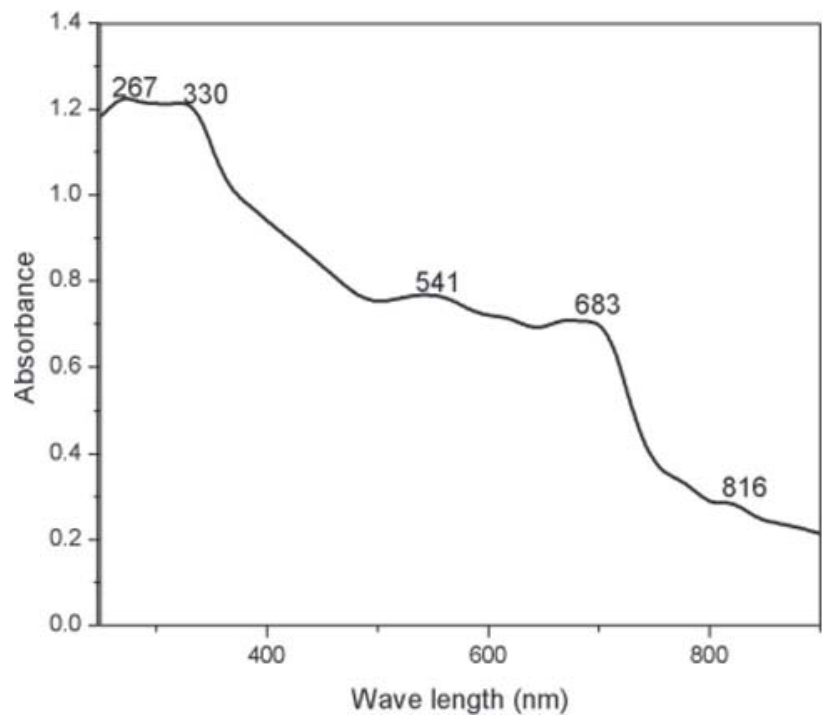

Figure 6. UV spectum of $\left[\mathrm{Co}(\mathrm{VTS})_{2}\right]$.

two bands at 260 and $310 \mathrm{~nm}$. The bands are due to $\pi \rightarrow \pi^{*}$ and $\mathrm{n} \rightarrow \pi^{*}$ transitions of $\mathrm{C}=\mathrm{N}$ group in the ligand field structure. On complexation, this band was found shifted to lower wavelength region indicating the coordination of ligand to the central metal ion. The magnetic moment value of cobalt(II) complex was 4.74 B.M. The electronic spectrum of cobalt complex exhibited three absorption bands at $816 \mathrm{~nm}, 683 \mathrm{~nm}$ and $541 \mathrm{~nm}$ assigned to transitions ${ }^{4} \mathrm{~T}_{1 \mathrm{~g}}(\mathrm{~F}) \rightarrow{ }^{4} \mathrm{~T}_{2 \mathrm{~g}}(\mathrm{~F})$, ${ }^{4} \mathrm{~T}_{1 \mathrm{~g}}(\mathrm{~F}) \rightarrow{ }^{4} \mathrm{~A}_{2 \mathrm{~g}}(\mathrm{~F})$ and ${ }^{4} \mathrm{~T}_{1 \mathrm{~g}}(\mathrm{~F}) \rightarrow{ }^{4} \mathrm{~T}_{1 \mathrm{~g}}(\mathrm{P})$, respectively indicating an octahedral geometry around the cobalt ion. ${ }^{33}$ Electronic spectrum of Ni(II) complex shows three bands at 590, 656 and $835 \mathrm{~nm}$ assignable to be ${ }^{3} \mathrm{~A}_{2 \mathrm{~g}}(\mathrm{~F}) \quad \rightarrow{ }^{3} \mathrm{~T}_{2 \mathrm{~g}}(\mathrm{~F}), \quad{ }^{3} \mathrm{~A}_{2 \mathrm{~g}}(\mathrm{~F}) \quad \rightarrow{ }^{3} \mathrm{~T}_{1 \mathrm{~g}}(\mathrm{~F}) \quad$ and ${ }^{3} \mathrm{~A}_{2 \mathrm{~g}}(\mathrm{~F}) \rightarrow{ }^{3} \mathrm{~T}_{1 \mathrm{~g}}(\mathrm{P})$ transitions, suggesting an octahedral geometry around the nickel(II) ion. The magnetic moment value of $\mathrm{Ni}$ (II) complex was 3.14 B.M., also confirms the octahedral geometry of the $\mathrm{Ni}$ (II) complex. ${ }^{34}$ The copper complex has a magnetic moment of 1.80 BM. It exhibits characteristic bands at $710 \mathrm{~nm}$ and $580 \mathrm{~nm}$ which are due to ${ }^{2} \mathrm{~B}_{1 \mathrm{~g}} \rightarrow{ }^{2} \mathrm{~A}_{1 \mathrm{~g}}$ and ${ }^{2} \mathrm{~B}_{1 \mathrm{~g}} \rightarrow{ }^{2} \mathrm{E}_{\mathrm{g}}$ transitions respectively. ${ }^{35}$ The magnetic moment along with spectral evidence confirms the square planar structure. The diamagnetic mononuclear $\mathrm{Zn}$ (II) complex gave only intra ligand transitions at $281 \mathrm{~nm}$ and $352 \mathrm{~nm}$, with a mononuclear tetrahedral geometry around the central metal atom. $\mathrm{Zn}$ (II) complex show an absorption band at $485 \mathrm{~nm}$ which could be assigned to the ligand to metal charge transfer transitions. ${ }^{36}$ The electronic spectra of ligand and its complexes are given in Figures 5 to 9.

\subsection{Mass spectrum of HVTS and its complexes}

The ESI mass spectra of the ligand HVTS and its complexes are given in supplementary information. The mass spectrum of the HVTS shows a peak at 316.1124 [HVTSC $+\mathrm{H}]^{+}$. The molecular ion peak $(\mathrm{M}+1)$ was found as the base peak in the case of vanillin-4-methyl-4-phenyl-3-thiosemicarbazone. The peak at 338. 09434 is due to the adduction $[\text { HVTSC }+\mathrm{Na}]^{+}$. The observed $\mathrm{m} / \mathrm{z}$ value of the ligand is in good agreement with the calculated value. The mass spectrum of $\left[\mathrm{Co}(\mathrm{VTS})_{2}\right]$ shows a peak at 687.12616 which is due to the molecular ion peak itself. The calculated molecular weight for the Co(II) complex is the same as that of observed one in the

Table 1. XRD data of the VTSC and its complexes.

\begin{tabular}{lrrrcrcr}
\hline & \multicolumn{3}{c}{ Lattice constant $(\AA)$} & & & \\
\cline { 2 - 4 } Ligand/complexes & \multicolumn{1}{c}{$\mathrm{a}$} & \multicolumn{1}{c}{$\mathrm{b}$} & $\mathrm{c}$ & Inter axial angle $\left(^{\circ}\right)$ & Space group & Crystal system \\
\hline HVTS & 11.12 & 6.19 & 14.32 & $\alpha=\gamma=90, \beta \neq 90$ & $\mathrm{P} 2_{1} / \mathrm{n}$ & Monoclinic \\
{$\left[\mathrm{Co}(\mathrm{VTS})_{2}\right]$} & 9.26 & 14.73 & 20.19 & $\alpha=\gamma=90, \beta \neq 90$ & $\mathrm{P} 2_{1} / \mathrm{c}$ & Monoclinic \\
{$\left[\mathrm{Ni}(\mathrm{VTS})_{2}\right]$} & 7.01 & 3.23 & 6.68 & $\alpha=\gamma=90, \beta \neq 90$ & $\mathrm{C} 2 / \mathrm{m}$ & Monoclinic \\
{$[\mathrm{Cu}(\mathrm{VTS}) \mathrm{Cl}] .2 \mathrm{H}_{2} \mathrm{O}$} & 4.70 & 11.29 & 7.09 & $\alpha=\gamma=90, \beta \neq 90$ & $\mathrm{P} 2{ }_{1} / \mathrm{m}$ & Monoclinic \\
{$[\mathrm{Zn}(\mathrm{VTS}) \mathrm{Cl}]$.} & 15.29 & 23.62 & 6.01 & $\alpha=\gamma=90, \beta \neq 90$ & $\mathrm{C} 2 / \mathrm{c}$ & Monoclinic \\
\hline
\end{tabular}




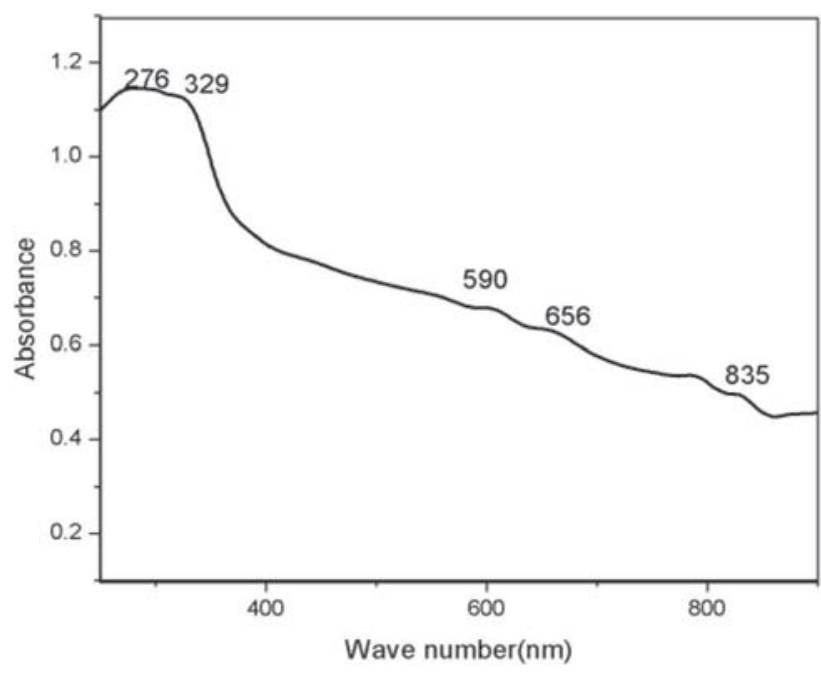

Figure 7. UV spectrum of $\left[\mathrm{Ni}(\mathrm{VTS})_{2}\right]$.

mass spectrum. Additional peaks present at 314.09658 and 172.07167 is due to the presence of VTS and [VTS $-\mathrm{C}_{8} \mathrm{H}_{8} \mathrm{NS}+\mathrm{Na}$ ]. The mass spectrum of $\mathrm{Ni}$ (II) complex was found to show a peak at 687.13831, which is the molecular ion peak itself. The base peak at 373.03333 is due to the $[\mathrm{M}+\mathrm{VTS}]^{+}$. The value obtained from the mass spectra is the same as that of the calculated value. The mass spectrum of the $\mathrm{Cu}$ (II) complex contains peak at 450.06440 due to the molecular ion $\left[\mathrm{M}+\mathrm{VTS}+\mathrm{Cl}+2 \mathrm{H}_{2} \mathrm{O}\right]^{+}$. The base peak at 402.05969 is due to the presence of [M+VTS+Na] and other peaks at 378.03333 and 314.09747 are due to the presence of [M+VTS] and [VTS]. The structure of $\mathrm{Cu}$ (II) complex was also confirmed by the mass spectrum. The mass spectrum of the $[\mathrm{Zn}(\mathrm{VTS}) \mathrm{Cl}]$ exhibits a base peak at 415.05303 due to the presence of adduct ion $[\mathrm{M}+\mathrm{VTS}+\mathrm{Cl}]^{+}$. The base peak at 380.02659 is due to the ion $[\mathrm{M}+\mathrm{VTS}]^{+}$and the peak at 316.11268 indicates the presence of ligand ion.

From the above studies, the complexes could be formulated as $\left[\mathrm{M}(\mathrm{VTSC})_{2}\right], \quad \mathrm{M}=\mathrm{Co}(\mathrm{II}), \mathrm{Ni}(\mathrm{II})$, $[\mathrm{Cu}(\mathrm{VTSC}) \mathrm{Cl}] \cdot 2 \mathrm{H}_{2} \mathrm{O}$ and $[\mathrm{Zn}(\mathrm{VTSC}) \mathrm{Cl}]$. On the basis

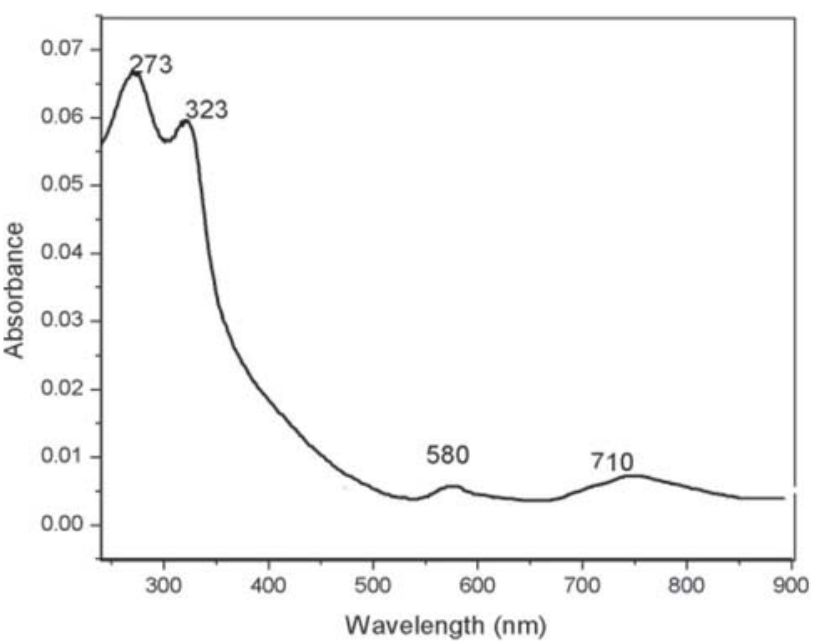

Figure 8. UV spectrum of $[\mathrm{Cu}(\mathrm{VTS}) \mathrm{Cl}] \cdot 2 \mathrm{H}_{2} \mathrm{O}$.

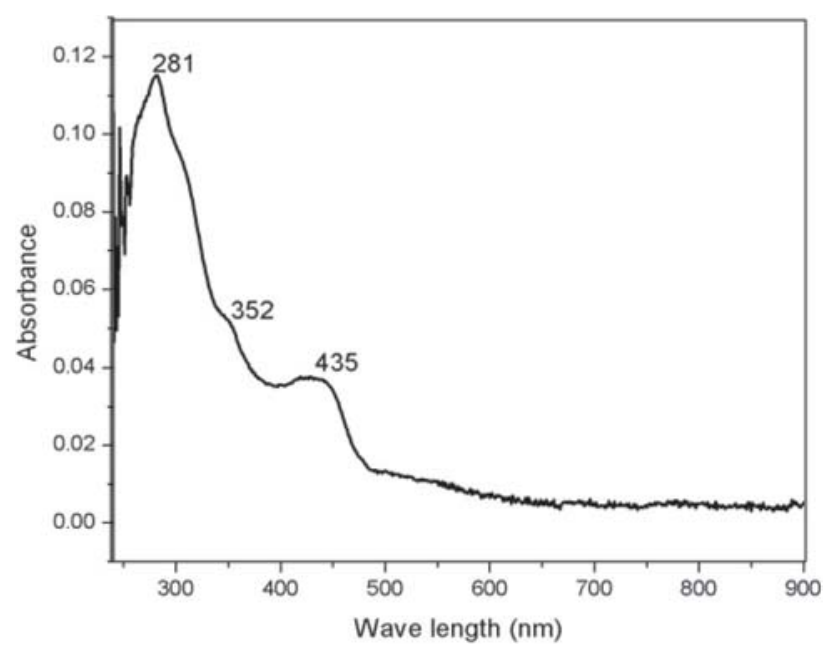

Figure 9. UV spectrum of $[\mathrm{Zn}(\mathrm{VTS}) \mathrm{Cl}]$.

of the previously discussed physicochemical values and spectral data, the structure of the ligand and complexes could be assigned as shown in Figure 10.

Table 2. Antimicrobial studies of ligand and its complexes.

\begin{tabular}{|c|c|c|c|c|c|c|}
\hline Sample & E. coli & K. pneu & B.cereus & S. Aureus & A. niger & Penicillium sp. \\
\hline HVTS & 14 & 15 & 10 & 8 & 8 & 9 \\
\hline$\left[\mathrm{Co}(\mathrm{VTS})_{2}\right]$ & 19 & 17 & 15 & 19 & 10 & 12 \\
\hline$\left[\mathrm{Ni}(\mathrm{VTS})_{2}\right]$ & 20 & 23 & 22 & 26 & 11 & 13 \\
\hline$[\mathrm{Cu}(\mathrm{VTS}) \mathrm{Cl}] 2 \mathrm{H}_{2} \mathrm{O}$ & 21 & 27 & 25 & 30 & 10 & 11 \\
\hline$[\mathrm{Zn}(\mathrm{VTS}) \mathrm{Cl}]$ & 28 & 25 & 24 & 26 & 13 & 13 \\
\hline Gentamycine & 26 & 28 & 22 & 24 & & \\
\hline Clotrimazole & & & & & 20 & 22 \\
\hline
\end{tabular}

Antibacterial activity: $<12$ mm-weak activity, 12-16-moderately active: $>16$-significant activity. Antifungal activity: $<7 \mathrm{~mm}$-weekly active; $9-7 \mathrm{~mm}$-moderate active; $>10 \mathrm{~mm}$-significant activity. 
<smiles>C=C(/C=N/NC(=S)N(C)c1ccccc1)C(O)=COC</smiles>

(a)

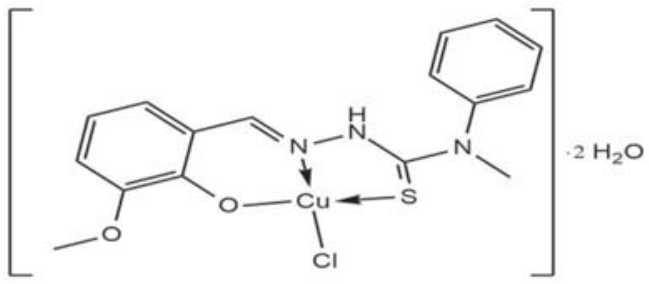

(c)

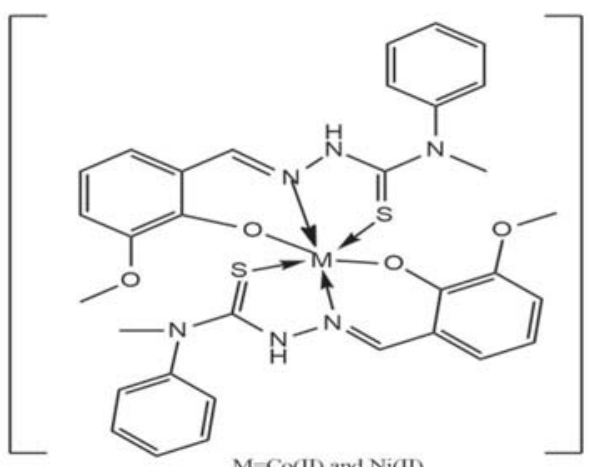

(b)

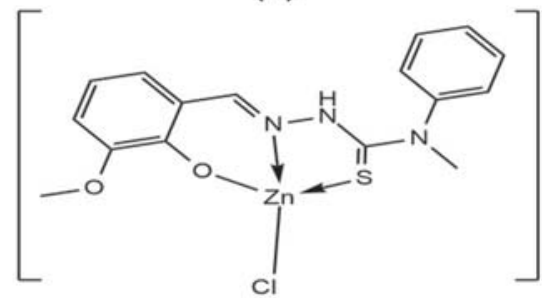

(d)

Figure 10. Structure of (a) ligand (b) $\mathrm{Co}(\mathrm{II}) \& \mathrm{Ni}(\mathrm{II})$ complexes (c) $\mathrm{Cu}$ (II) complex (d) $\mathrm{Zn}$ (II) complex.

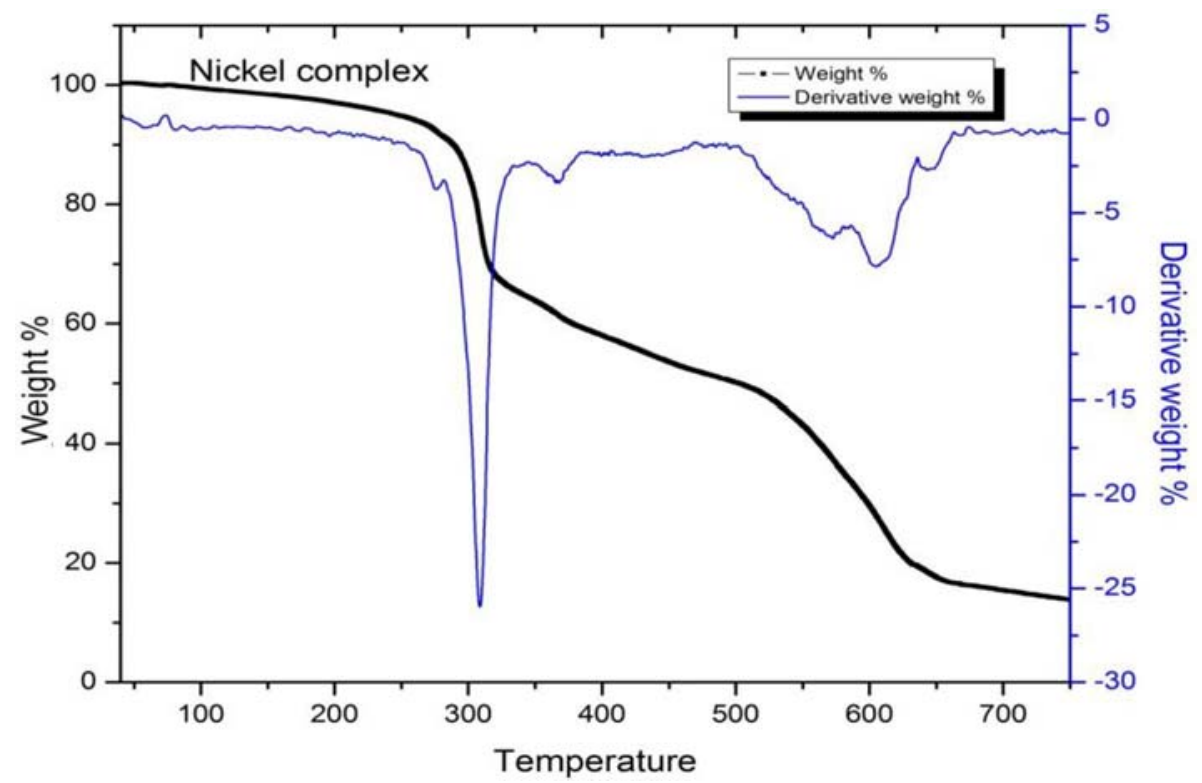

Figure 11. TG-DTG curve of $\left[\mathrm{Ni}(\mathrm{VTS})_{2}\right]$.

\subsection{Thermogravimetric analysis}

The thermal stability of the complex was studied by using thermo gravimetrical analysis. Cobalt, nickel and zinc complexes are thermally stable above $275^{\circ} \mathrm{C}$, which indicate the absence of water molecule. These complexes were found to decompose in a two-step process. The first decomposition for cobalt complex occurs between $280-320^{\circ} \mathrm{C}$ with an endothermic peak at $303{ }^{\circ} \mathrm{C}$, and the second decomposition from $600{ }^{\circ} \mathrm{C}$ with an endothermic peak at $628{ }^{\circ} \mathrm{C}$. The thermal 


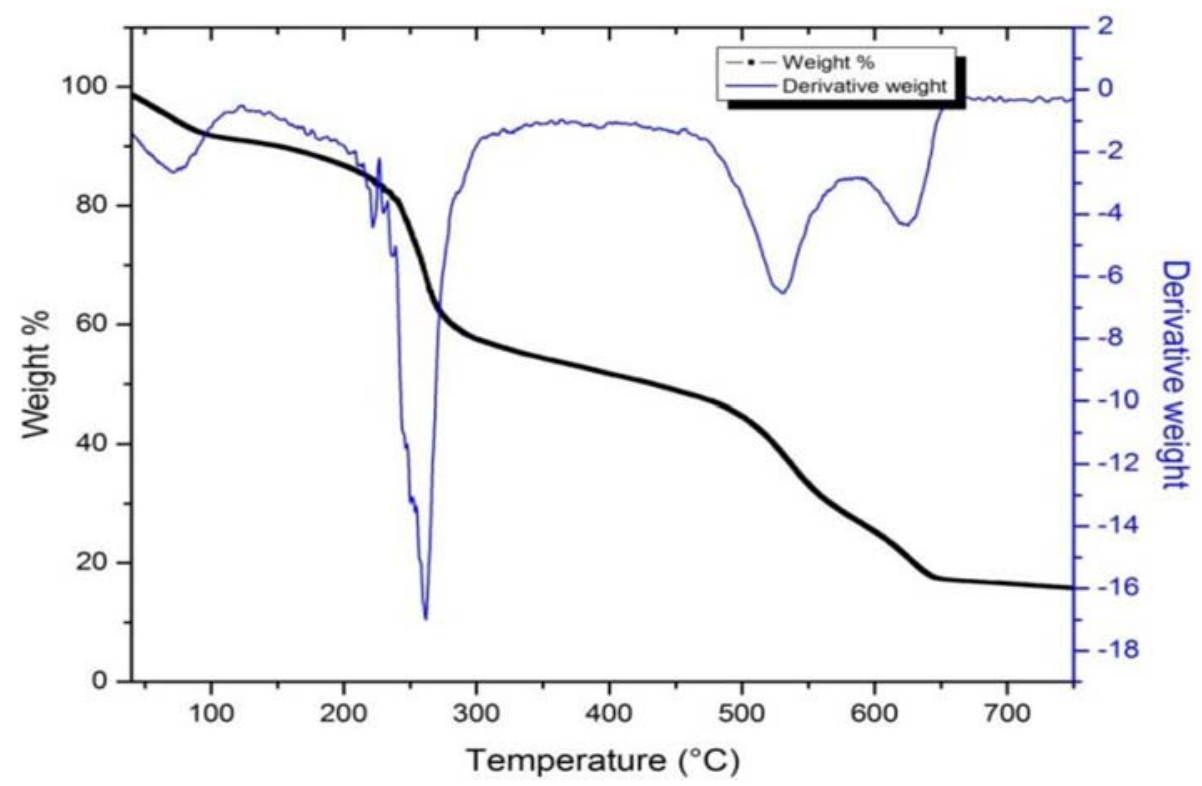

Figure 12. TG-DTG curve of $[\mathrm{Cu}(\mathrm{VTS}) \mathrm{Cl}] \cdot 2 \mathrm{H}_{2} \mathrm{O}$.

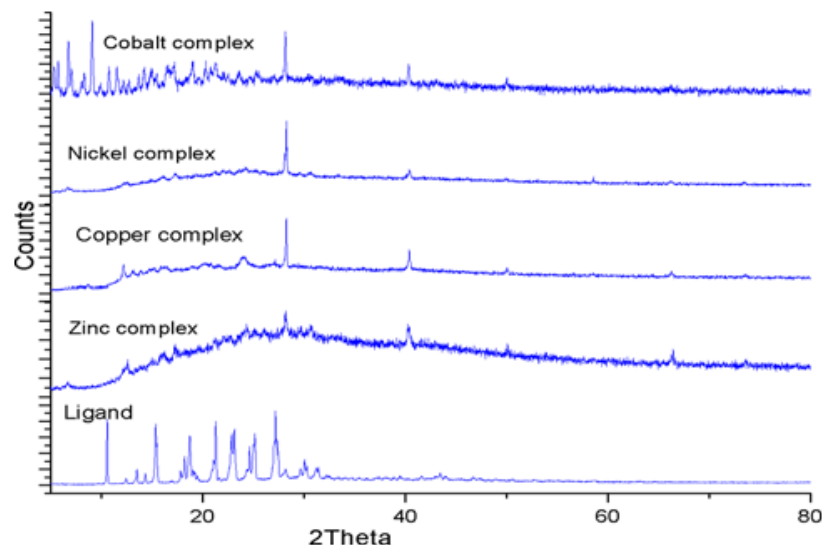

Figure 13. PXRD spectrum of ligand and its complexes.

decomposition of nickel complex starts from $275{ }^{\circ} \mathrm{C}$ with an endothermic peak at $308{ }^{\circ} \mathrm{C}$ and the second decomposition occurs from 550-670 with an endothermic peak at $570{ }^{\circ} \mathrm{C}$. Copper complex decomposed in between $70-90{ }^{\circ} \mathrm{C}$ with an endothermic peak of 81 indicating the presence of lattice water. Spectral data of the complex also confirms the presence of water molecule. ${ }^{37}$ Second decomposition starts at $220{ }^{\circ} \mathrm{C}$ indicating the presence of chloride ion in the complex. The final decomposition occurs above 550 ${ }^{\circ} \mathrm{C} .{ }^{38}$ All the complexes remained as metal residue above $700{ }^{\circ} \mathrm{C} .{ }^{39}$ The TG-DTG curves of nickel and copper complexes are shown in Figure 11 and Figure 12.

\subsection{Powder XRD analysis}

The powder X-ray diffraction patterns of the ligand and its complexes were recorded in the range of $2 \theta=5$ to $80^{\circ}$. Sharp crystalline peaks were observed for the ligand and complexes, indicating crystalline behavior of the samples. ${ }^{40}$ All the complexes exhibited sharp peaks in the XRD diagrams. The powder XRD analysis of the ligand and the complexes are shown in Figure 13.

The average grain size of the complexes were calculated using Debye Scherer equation $\left[\mathrm{d}_{\mathrm{XRD}}=0.9 \lambda /\right.$ $\beta \cos \theta]$. The grain size of the ligand, cobalt, nickel, copper (II) and zinc (II) complexes were 36.1, 81.4, $57.6,47.6$ and $33.4 \mathrm{~nm}$ respectively, indicating that the metal complexes fall in the nano regime. The ligand and complexes belong to a monoclinic crystal system with a different space group. The lattice parameters and the space group are given in Table 1 .

\subsection{SEM analysis}

The surface morphology of metal complexes was analyzed using a scanning electron microscope and is shown in Figure 7. SEM images with a magnification value of 3,500X and optimum energy value of $20 \mathrm{kV}$ were used for the analysis. The SEM images of the complexes were found entirely different from that of the ligands. The surface of the ligand seems to have a cylindrical rod-like structure. The cobalt complex exhibits an agglomerated irregular spherical shape 

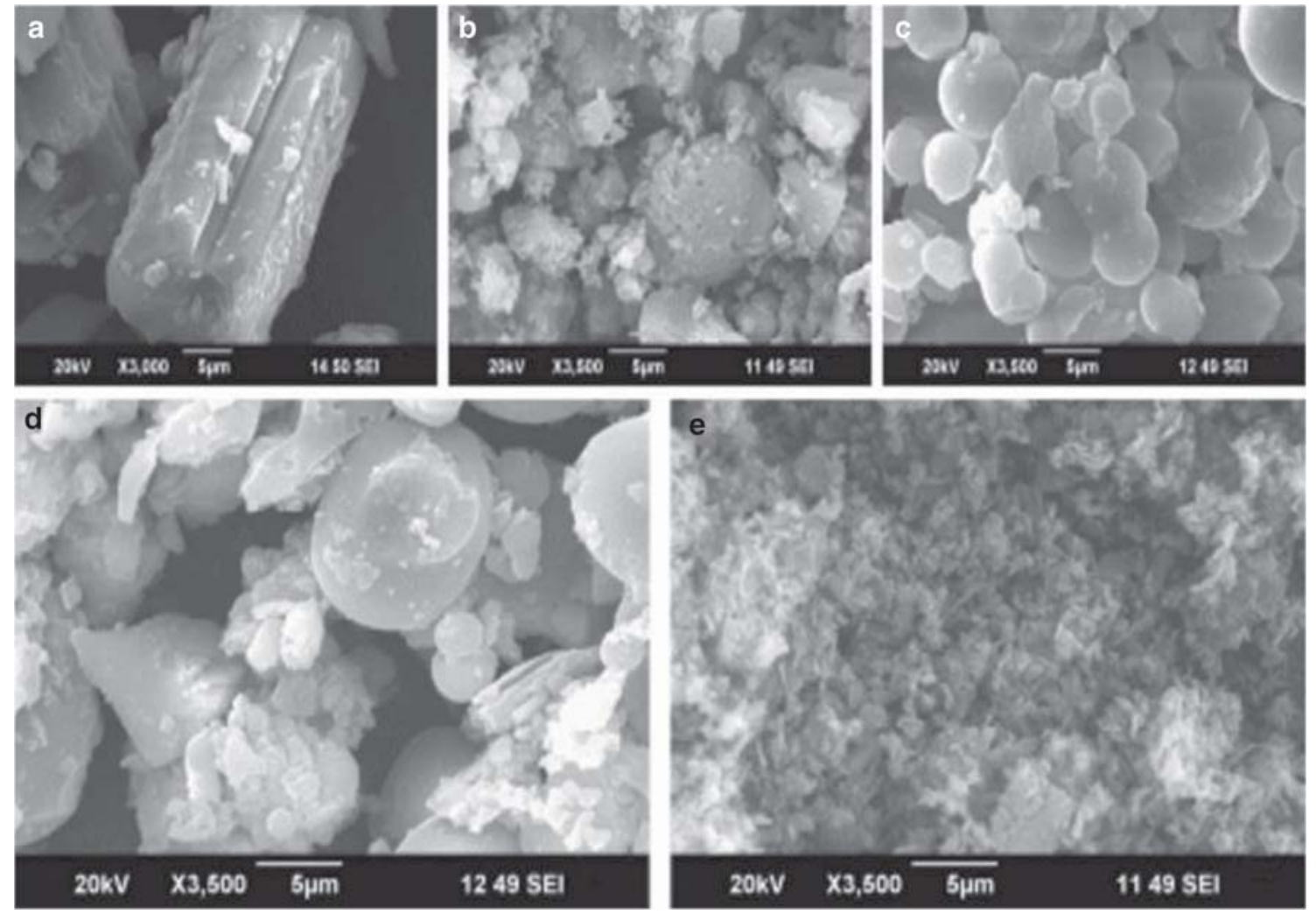

Figure 14. SEM images of (a) ligand (b) $\mathrm{Co}$ (II) (c) $\mathrm{Ni}$ (II) (d) $\mathrm{Cu}$ (II) (e) $\mathrm{Zn}$ (II) complexes.

surface morphology while the nickel complex was found to have a homogenous circular plate-like structure. The copper complex contained agglomerated spherical like particles ${ }^{41}$ and the zinc complexes had heterogeneous spherical particles. All the complexes are polycrystalline with nano-sized grains.

\subsection{Antimicrobial studies}

Antimicrobial activities of vanillin-4-methyl-4-phenyl-3-thiosemicarbazone and its complexes were determined by agar well diffusion method. In our study, activities were checked against two Gram-positive bacteria namely- Staphylococcus aureus and Bacillus cereus, two gram-negative bacteria- Escherichia coli and Klebsiella pneumonia and two fungal pathogens -Aspergillus niger and Penicillium sp. The zone of inhibition of samples against different bacteria and fungi are given in Table 2 .

The antimicrobial activity data of the thiosemicarbazone and complexes indicates that all the complexes have had better activity than that of the ligand. ${ }^{42}$ The antibacterial activity of the complexes were higher than that of antifungal activity. ${ }^{43}$ The variation in the activity of the complexes against different organism depends on the impermeability of the cell of the microbe. The copper and zinc complex show maximum activity against bacteria. The increased activities of the metal complexes than that of free ligand are explained on the basis of chelation theory according to which chelation is considered to reduce the polarity of the metal ions due to the partial sharing of its positive charge with the ligand. ${ }^{44}$ This increases the lipid solubility which favours its permeation into normal cell of the microbes.

\section{Conclusions}

The vanillin thiosemicarbazone and its cobalt(II), nickel(II), copper(II) and zinc(II) complexes were characterized through elemental analysis, molar conductivity, magnetic moment, electronic spectra, infrared spectra, ${ }^{1} \mathrm{H},{ }^{13} \mathrm{C}$ NMR spectra, thermogravimetric analysis, powder XRD analysis and SEM analysis. Based on the data, an octahedral geometry was assigned for the cobalt and nickel complex, square planar geometry for copper complex and a tetrahedral geometry for zinc complex. The ligand act as 
tridentate coordinating via azomethine nitrogen, a sulphur atom and a phenolic oxygen atom. The complexes are non-electrolytic in nature. All complexes except copper complex were stable upto $280{ }^{\circ} \mathrm{C}$. Powder XRD analysis suggests that the ligand and complexes belongs to a monoclinic crystal system with a different space group. The complexes were found to possess crystal size less than $70 \mathrm{~nm}$, which increases the possibility of their use as nano precursors. The surface analysis of the complexes was entirely different from the ligand. Copper and zinc complexes of vanillin thiosemicarbazone were found to possess high antibacterial and antifungal activity as compared with other complexes.

\section{Supplementary Information (SI)}

Figures S1-S5 are available as supplementary information at www.ias.ac.in/chemsci.

\section{Acknowledgements}

One of the author (Lekshmi V Kumar) acknowledge the CSIR, New Delhi for the financial support through the grant no. 08/537(0004)/2014 EMR-1, dated 27/08/2014. Authors are thankful to STIC, CUSAT, Kochi for the instrumental analysis of samples, SICC, University of Kerala, Thiruvananthapuram for PXRD analysis.

\section{References}

1. Ramachandran E, Raja D S, Bhuvanesh N S P and Natarajan K 2013 Synthesis, characterization and in vitro pharmacological evaluation of new water soluble $\mathrm{Ni}$ (II) complexes of $4 \mathrm{~N}$-substituted thiosemicarbazones of 2-oxo-1,2-dihydroquinoline-3-carbaldehyde Eur. J. Med. Chem. 64179

2. Kumar A V, Sarala Y, Asha S, Vanitha S, Babu S and Reddy A V 2018 Synthesis, Characterization Antimicrobial and Antioxidant Activities of 2,4-dihydroxybenzaldehyde-4-phenyl-3-thiosemicarbazone

(DHBPTSC) and its Pd(II), Ni(II) mixed Ligand and $\mathrm{Cu}(\mathrm{II})$ Complex having Heterocyclic Bases J. Appl. Pharm. Sci. 8471

3. Shawish H B, Maah M, Halim S N A and Shaker S A 2016 Synthesis, characterization and structural studies of binuclear nickel(II) complexes derived from dihydroxybenzaldehyde thiosemicarbazones, bridged by 1,2-bis(diphenylphosphino)ethane Arab. J. Chem. 9 1935

4. Kumar S M, Dhahagani K, Rajesh J, Nehru K, Annaraj J, Chakkaravarthi G and Rajagopal G 2013 Synthesis, characterization, structural analysis and DNA binding studies of nickel(II)-triphenylphosphine complex of ONS donor ligand - Multisubstituted thiosemicarbazone as highly selective sensor for fluoride ion Polyhedron 5958
5. Latheef L and Kurup M R P 2008 Spectral and structural studies of nickel(II) complexes of salicylaldehyde 3-azacyclothiosemicarbazones Polyhedron 2735

6. Mosa A I, Ibrahim M M and Aldhlmani S A 2013 Spectroscopic and Solution Studies of Some Transition Metal Complexes of New 4-Hydroxy Coumarin Semiand Thiosemicarbazone Complexes J. Sol. Chem. 42 2364

7. Graiff C, Canossa S and Predier G 2014 coordinative properties of the pyridine-2- carbaldehyde thiosemicarbazone ligand towards Ni(ii) J. Mol. Struct. 55493

8. Yousef T A, Abu El-Reash G M, O A El-Gammal and Bedier R A 2013 Synthesis, characterization, optical band gap, in vitro antimicrobial activity and DNA cleavage studies of some metal complexes of pyridyl thiosemicarbazone J. Mol. Struct. 1035307

9. Ali A Q, Teoh S G, Eltayeb N E, Ahamed M K B and Abdul Majid A M S 2014 Synthesis of copper(II) complexes of isatin thiosemicarbazone derivatives: In vitro anti-cancer, DNA binding, and cleavage activities Polyhedron 746

10. Prathima B, Rao Y S, Reddy S A, Reddy Y P and Reddy A V 2010 Copper(II) and nickel(II) complexes of benzyloxybenzaldehyde-4- phenyl-3-thiosemicarbazone: Synthesis, characterization and biological activity Spectrochim. Part A: Mol. Biomol. Spectrosc. 77248

11. Cao w, Qi j, Qian K, Tian L, Cheng Z and Wang Y 2019 Structure-activity relationships of 2-quinolinecarboxaldehyde thiosemicarbazone gallium(III) complexes with potent and selective anticancer activity J. Inorg. Biochem. 191174

12. Alomar K, Landreau A, Allain M, Bouet G and Larcher G 2013 Synthesis, structure and antifungal activity of thiophene-2,3-dicarboxaldehyde bis(thiosemicarbazone) and nickel(II), copper(II) and cadmium(II) complexes: Unsymmetrical coordination mode of nickel complex J. Inorg. Biochem. 12676

13. Mbah J A, Ayimele G A, Eyonganyoh E N and Nfor E N 2017 Synthesis, Molecular Structure and Antibacterial Activity of Benzylmethyl-4-Methyl-3-Thiosemicarbazone Int. J. Org. Chem. 783

14. Aljahdali M and EL-Sherif A A 2013 Synthesis, characterization, molecular modeling and biological activity of mixed ligand complexes of $\mathrm{Cu}(\mathrm{II}), \mathrm{Ni}(\mathrm{II})$ and $\mathrm{Co}$ (II) based on 1,10-phenanthroline and novel thiosemicarbazone Inorg. Chim. Acta 40758

15. El-Sawaf A K, El-Essawy F, Nassar A A and El-Samanody E A 2018 Synthesis, spectral, thermal and antimicrobial on cobalt(II), nickel(II), copper(II), zinc(II) and palladium(II) complexes containing thiosemicarbazone ligand J. Mol. Struct. 1157381

16. Piri Z, Moradi-Shoeili Z and Assoud A 2019 Ultrasonic assisted synthesis, crystallographic, spectroscopic studies and biological activity of three new $\mathrm{Zn}$ (II), $\mathrm{Co}$ (II) and $\mathrm{Ni}(\mathrm{II})$ thiosemicarbazone complexes as precursors for nano-metal oxides Inorg. Chim. Acta 484338

17. Pawar A S, Mlowe S, Garje S S, Akerman M P and Revaprasadu N 2017 Zinc thiosemicarbazone complexes: single source precursors for alkylamine capped $\mathrm{ZnS}$ nanoparticles Inorg. Chim. Acta 7463 
18. Rai B K, Kumar S, Anand R and Pandey A 2013 Spectral and Antimicrobial Screening of $\mathrm{Cu}(\mathrm{II}), \mathrm{Ni}(\mathrm{II})$ and $\mathrm{Co}$ (II) Coordination Compounds with Nitrogen Oxygen and Sulphur Containing Tridentate Schiff Base Orient. J. Chem. 29655

19. Nair M S and Joseyphus R S 2008 Synthesis and characterization studies of $\mathrm{Co}(\mathrm{II}), \mathrm{Ni}(\mathrm{II}), \mathrm{Cu}(\mathrm{II})$ and $\mathrm{Zn}$ (II) complexes of tridentate Schiff base derived from vanillin and DL- $\alpha$-aminobutyric acid Spectrochim. Acta Part A 70749

20. Sharma S, Athar F, Maurya M R and Azam A 2005 Copper(II) complexes with substituted thiosemicarbazones of thiophene-2-carboxaldehyde: synthesis, characterization and antiamoebic activity against E. Histolytica Eur. J. Med. Chem. 401414

21. Muralisankar M, Sujith S, Bhuvanesh N S P and Sreekanth A 2016 Synthesis and crystal structure of new monometallic and bimetallic copper(II) complexes with $\mathrm{N}$-substituted isatin thiosemicarbazone ligands: Effects of the complexes on DNA/protein-binding property, DNA cleavage study and in vitro anticancer activity Polyhedron 118103

22. Aly A A, Brase S and Weis P 2019 Tridentate and bidentate copper complexes of [22] paracyclophanylsubstituted thiosemicarbazones, thiocarbazones, hydrazones and thioureas J. Mol. Struct. 1178311

23. Kumar S M, Dhahagani K, Rajesh J, Nehru K, Annaraj J, Chakkaravarthi G and Rajagopal G 2013 Synthesis, characterization, structural analysis and DNA binding studies of nickel(II)-triphenylphosphine complex of ONS donor ligand - Multisubstituted thiosemicarbazone as highly selective sensor for fluoride ion Polyhedron 5958

24. Mosa A I, Emara A A A, Yousef J M and Saddiq A A 2011 Novel transition metal complexes of 4-hydroxycoumarin-3-thiocarbohydrazone: Pharmacodynamic of $\mathrm{Co}(\mathrm{III})$ on rats and antimicrobial activity Spectrochim. Part A 8135

25. Guveli S, Ozdemir N, Koca A, Bal-Demirci T and Ulkuseven B 2016 Spectroscopic, electrochemical and $\mathrm{X}$-ray diffraction studies on nickel(II)-complexes of acetophenone thiosemicarbazones substituted six-carbon groups Inorg. Chim. Acta 7443

26. Datta S, Seth D K, Gangopadhyay S, Karmakar P and Bhattacharya S 2012 Nickel complexes of some thiosemicarbazones: Synthesis, structure, catalytic properties and cytotoxicity studies Inorg. Chim. Acta 392118

27. Mishra P M, Kumar M, Chaudhary R S and Kumar C 2013 Synthesis and Characterization of Divalent Transition Metal Complexes Containing Thiosemicarbazone Ligands Orient. J. Chem. 291651

28. El-Asmy A A and Al-Hazmi G A A 2009 Synthesis and spectral feature of benzophenone-substituted thiosemicarbazones and their $\mathrm{Ni}(\mathrm{II})$ and $\mathrm{Cu}(\mathrm{II})$ complexes Spectrochim. Part A 711885

29. Wang B, Yang Z, Lü Z, Hai J, Wang Q and Chen Z 2009 Synthesis, characterization, cytotoxic activity and DNA binding $\mathrm{Ni}$ (II) complex with the 6-hydroxy chromone-3-carbaldehyde thiosemicarbazone J. Organomet. Chem. 6944069
30. Devi J, Yadav M and Sharma S O 2018 Synthesis and Characterization of Transition Metal(II) Schiff Bases Complexes Derived from 2,5-Dihalosalicylaldehyde and 4-Methyl-3-thiosemicarbazide Asian J. Chem. 30 2445

31. Ferraz K O, Wardell S M S V, Wardell J L, Louro S R W and Beraldo H 2009 Copper(II) complexes with 2-pyridineformamide-derived thiosemicarbazones: Spectral studies and toxicity against Artemia Spectrochim. Part A $\mathbf{7 3} 140$

32. Kovala-Demertzi D, Alexandratos A, Papageorgiou A, Yadav P N, Panagiotis Dalezis, and Demertzis M A 2008 Synthesis, characterization, crystal structures, in vitro and in vivo antitumor activity of palladium(II) and zinc(II) complexes with 2-formyl and 2-acetyl pyridine N(4)-1-(2-pyridyl)-piperazinyl thiosemicarbazone Polyhedron 272731

33. Abou-Melha K S 2008 Octahedral Co(II) and Ni(II) complexes of Schiff bases, semicarbazone and thiosemicarbazone, synthesis, biological, spectral, and thermal Studies J. Coord. Chem. 612053

34. Sinha B, Bhattacharya M and Saha S 2019 Transition metal complexes obtained from an ionic liquid-supported Schiff base: synthesis, physiochemical characterization and exploration of antimicrobial activities $J$. Chem. Sci. 13119

35. Matović D Z, Ristic B, Joksovic M and Trifunovic S R 2000 Square-planar copper(II) complexes with a novel tetradentate amido-carboxylate ligand. Crystal structure of $\left[\mathrm{Co}\left(\mathrm{H}_{2} \mathrm{O}\right)_{6}\right][\mathrm{Cu}(\mathrm{mda})] \cdot 2 \mathrm{H}_{2} \mathrm{O}$ Trans. Met. Chem. 25720

36. Nair M S, Arish D and Joseyphus R S 2012 Synthesis, characterization, antifungal, antibacterial and DNA cleavage studies of some heterocyclic Schiff base metal complexes J. Saudi Chem. Soc. 1683

37. Saif M, Mashaly M M, Eid M F and Fouad R 2012 Synthesis, characterization and thermal studies of binary and/or mixed ligand complexes of $\mathrm{Cd}(\mathrm{II}), \mathrm{Cu}(\mathrm{II})$, $\mathrm{Ni}$ (II) and $\mathrm{Co}$ (III) based on 2-(Hydroxybenzylidene) thiosemicarbazone: DNA binding affinity of binary Cu(II) complex Spectrochim. Part A 92347

38. Reddy D H K, Lee S, Seshaiah K and Babu K R 2012 Synthesis, characterization of thiosemicarbazone metal complexes and their antioxidant activity in different in vitro model systems J. Serb. Chem. Soc. 77229

39. Refat M S, El-Deen I M, Anwer Z M and El-Ghol S 2009 Bivalent transition metal complexes of coumarin3-yl thiosemicarbazone derivatives: Spectroscopic, antibacterial activity and thermogravimetric studies $J$. Mol. Struct. 920149

40. Joseyphus S R and Nair M S 2010 Synthesis, characterization and biological studies of some $\mathrm{Co}(\mathrm{II}), \mathrm{Ni}(\mathrm{II})$ and $\mathrm{Cu}$ (II) complexes derived from indole-3-carboxaldehyde and glycylglycine as Schiff base ligand Arab. J. Chem. 3195

41. Lekshmi V K and Nath G R 2018 Synthesis and Characterization Studies of Cobalt(II), Nickel(II), Copper(II) and Zinc(II) Complexes of CarboxymethylN-Methyl-N-Phenyl Dithiocarbamate Orient. J. Chem. 343064 
42. Chandra S and Tyagi M 2009 Synthesis and antimicrobial activities of n-s donor ligand and its transition metal complexes Int. J. Chem. Sci. 7116

43. Netalkar P P, Netalkar S P and Revankar V K 2014 Nickel(II) complexes of thiosemicarbazones: synthesis, characterization, X-ray crystallographic studies and in vitro antitubercular and antimicrobial studies Trans. Met. Chem. 39519

44. Beckford F A and Webb K R 2017 Copper complexes containing thiosemicarbazones derived from 6nitropiperonal: Antimicrobial and biophysical properties Spectrochim. Part A 183158 